\title{
PRACTICAL USE OF DIGITALIZATION IN GEODESY AND LAND MANAGEMENT
}

\author{
V. Artemov, PhD \\ ORCID ID: 0000-0001-9121-1062 \\ T. Movchan, PhD \\ ORCID ID: 0000-0002-8914-2632 \\ L. Vikulina, PhD \\ ORCID ID: 0000-0002-0979-165X \\ Odessa State Agrarian University
}

https://doi.org/110.31734/economics2020.27.167

Артемов В., Мовчан Т., Вікуліна Л. Практичне використання цифровізації в геодезії та землеустрої

Досліджено стан цифровізації в Україні, показано, як практично вона впроваджується в геодезії та землеустрої. Цифрова революція дуже відчутна на виробництві, вона може призвести до зникнення низки масових і традиційних для нашої країни професій. Досліджувана галузь не може існувати без цифрових технологій через те, що землевпорядні вишукування (інженерно-геодезичні, інженерно-геологічні, інженерно-економічні, інженерногідрометеорологічні та інженерно-технічні) виконуються з використанням сучасного цифрового обладнання, а опрацювання їхніх результатів - за допомогою спеціального програмного забезпечення. Представлено власне бачення сутності цифровізації та цифрової трансформації в геодезії й землеустрої, зазначено, що це приводить до підвищення продуктивності праці та конкурентоспроможності в галузі. Проаналізовано особливості цифровізації та iï практичного впровадження для розробки агрохімічних паспортів. Запропоновано створити цифрову платформу в досліджуваній галузі, яка б стимулювала інновації, збільшила вибір, зручність, ринкову прозорість, забезпечила попит і пропозицію, скоротила витрати у сфері геодезії, землеустрою та кадастру. Відзначена необхідність створення переваг в отриманні сучасної землевпорядної освіти, проходженні здобувачами виробничої практики 3 використанням спеціального програмного забезпечення, організації нових робочих місць, розвитку підприємництва в галузі геодезії, землеустрою та кадастру. У навчальному процесі окреслена потреба в переорієнтуванні галузі на розширення сегмента знань у сфері цифрових технологій. Визначено, що вітчизняна геодезія має слабке науковотехнічне забезпечення через використання закордонного геодезичного обладнання та програмного забезпечення.

Ключові слова: цифровізація, цифрова трансформація, інформатизація, вишукування, агрохімічний паспорт, земельна ділянка, геодезія, картографія, геоінформаційні технології, землеустрій, кадастр.

\section{Artemov V., Movchan T., Vikulina L. Practical use of digitalization in geodesy and land management}

The article is devoted to the study of the current conditions of digitalization in Ukraine and how the digitalization is practically implemented in geodesy and land management. The digital revolution is very noticeable in production, it can lead to disappearance of the majority traditional professions. The studied industry cannot exist without digital technologies because land management surveys (engineering-geodetic, engineering-geological, engineering-economic, engineeringhydrometeorological and engineering-technical) are performed by using the modern digital equipment and the results processing is done with the special software. The vision of the essence of digitalization and digital transformation in geodesy and land management is presented in the work and it is stated that it will enhance labor efficiency and competitiveness in the industry. The peculiarities of digitization and its practical implementation for the development of agrochemical passports are analyzed. In the research area, it is proposed to create a digital platform, which would stimulate innovations, increase the options, convenience, and market transparency, meet supply and demand, reduce cost in the field of geodesy, land management and cadastre. The article also marks the necessity of creating advantages in obtaining modern land management education and passing industrial practice by applicants with the use of software. It is important to create new workplaces, to develop business in the considered industry. The educational process outlines the need to reorient the industry to expand the segment of knowledge in the field of digital technologies. It is pointed out that domestic geodesy has a weak scientific and technical support caused by the reliance on the imported foreign geodetic equipment and software.

Key words: digitalization, digital transformation, informatization, research, agrochemical passport, land plot, geodesy, cartography, geoinformation technologies, land management, cadastre.

Problem identification. Economy, geodesy, cartography, cadastre and land management are developing so rapidly that the necessity to use high advanced digital technology arises. These technologies need such changes as:
- adjustment of modern digital communication channels;

- implementation of multichannel and omnichannel strategy with a clear understanding, planning, analysis and flexibility approach; 

data;

- engagement of artificial intelligence for Big

- automate and robotize operational activity to boost employees productivity;

The model of the earth surface, coded in digital format according to the given structure, will be created and placed on the digital storage medium by:

- digitization of paper maps;

- photogrammetric processing of remote sensing data;

- field shooting using tools;

- office data processing of the field shooting and other methods.

Modern digitalization requires development of the newest geoinformation technology with traditional cartographic approaches to solution the tasks of geodesy, land management, land monitoring, land cadaster, control of use and land resources protection.

Analysis of the last researches and the publications. Digitalization has become a very important tool for economic growth of our country. The development of the digital economy in the United States and China is enforcing competition, increasing productivity, improving the skills of workers, falling prices, giving easy access to information and so on. Problems of digital economy formation were studied by V. Apalkova [5], S. Veretyuk, A. Glushenkova, O. Gudz [4], P. Doyle, P. Drucker, I. Zelisko, S. Kolyadenko, I. Karcheva, L. Lyamin, I. Malik, P. Stetsyuk, A. Thompson, E. Toffler, K. Schwab and others. The works by E. Bahchevan and T. Danko [1] were devoted to the problems of the digital transformation of the economy, researches of $\mathrm{V}$. Artemov, E. Bahchevan, T. Danko [2] were focused on the contemporary issues of electronic commerce, introduction the internet technologies in the economy, the studies of T. Movchan [3] illuminated to the problems of governance in the use and land resource protection. There are still unresolved issues of practical use of digitization in surveying and land management after all the opportunity to use digital technology in the industry grows every years because almost all modern surveying instruments, electronic devices and sensors require Internet connection now.

Setting objectives. To research the digitalization conditions in Ukraine and its practical implementation in geodesy and land management, which cannot exist without digital technology, since all searches are performed using digital equipment, and results are processed with the use of the appropriate software.
Presentation of the main material. The research on the development of GIS technology in geodesy, cadastre and land management, shows the need to proceed innovative information technology in land management activities of enterprises to increase their productivity. Land surveys such as engineering and geodetic, geotechnical, economic, meteorological and technical surveys, provide land management design with input data about the natural environment of land, promote correct and economically efficient choices of design solutions. Those works are performed with modern digital equipment, and the results are processed by appropriate software.

In order to control the dynamics of soil fertility, their agrochemical inspection is systematically carried out, agrochemical passports are issued, in which the initial and current levels of soil nutrient supply and their pollution levels are recorded. Passport information is required when transferring land ownership or providing land for use, including lease; change of land owner or land user; conducting monetary valuation of land; assessment of land taxes; monitoring the state of soil fertility. The National Research Center "Institute of Soil Science and Geochemistry named after O.N. Sokolovsky" of the National Academy of Agrarian Sciences of Ukraine has developed a computer program "Balance of humus and nutrients in agriculture of Ukraine", which allows calculating the balance of humus and nutrients in soils farms, crop rotations. These all data recorded in the agrochemical passport of the fields (land). The issuance of this document is very important for landowners, land users, because the results of agrochemical evaluation of the soil land are recorded in it. Agrochemical evaluation is based on the indicators of fertility (agrochemical score of the field) and score with the introduction of correction factors for soil contamination of the land parcel with radionuclides, heavy metals, pesticides, taking into account the climatic conditions of the territory, irrigation, drainage, salinization and other negative features. Thus, agrochemical and ecological-agrochemical assessment is evaluated in points. According to these indicators, the land is referred to the appropriate class of soil suitability from 1 to 10 (the highest soil productivity belongs to the first class).

It should be noted that the list of indicators given in the approved form of the agrochemical passport of the field is not mandatory for all soil and climatic zones. For example, hydrolytic and metabolic acidity are usually not included in the agrochemical passport of the field of the steppe zone, where the reaction of the medium with the $\mathrm{pH}$ of the aqueous 
suspension is determined, but for soils of Polissia and Forest-Steppe zones, these indicators are mandatory. To determine the qualitative assessment of soil throughout Ukraine, it is necessary to have information about of the maximum possible productive moisture supplies, humus content, movable forms of basic nutrition elements and minerals.

We have processed 38 agrochemical passports of fields (land plots) of Odessa region with an average field size of 16 hectares. Agrochemical (series 1) and ecological-agrochemical (series 2) assessment in points are presented in the Figure 1.

When agrochemical points look like growing series 1 , it is watched that the environmental points (series 2) almost repeat the pattern and the formula of trend lines have the same mathematical expression with minor differences of coefficients. The factor of reliability approximation $\mathrm{R}^{2}$ ( $\mathrm{R}$-squared) displays the extent of the trend model conformity to the output data and it is clear that they have almost identical values.

Relationship of the assessment points of the land plots state in the Figure 2, is approximated by linear function with coefficient of reliability approximation $\mathrm{R}^{2}=0,9941$, which confirms the close correlation between the given parameters and Pearson correlation coefficient, approaching to 1 . This can be explained by homogeneous and constant contamination in all areas of soil due to the absence of production with significant harmful emissions. However, taking into account the small statistical volume of data, it is of interest to continue the study of this phenomenon with an increased number of land parcels in different regions.

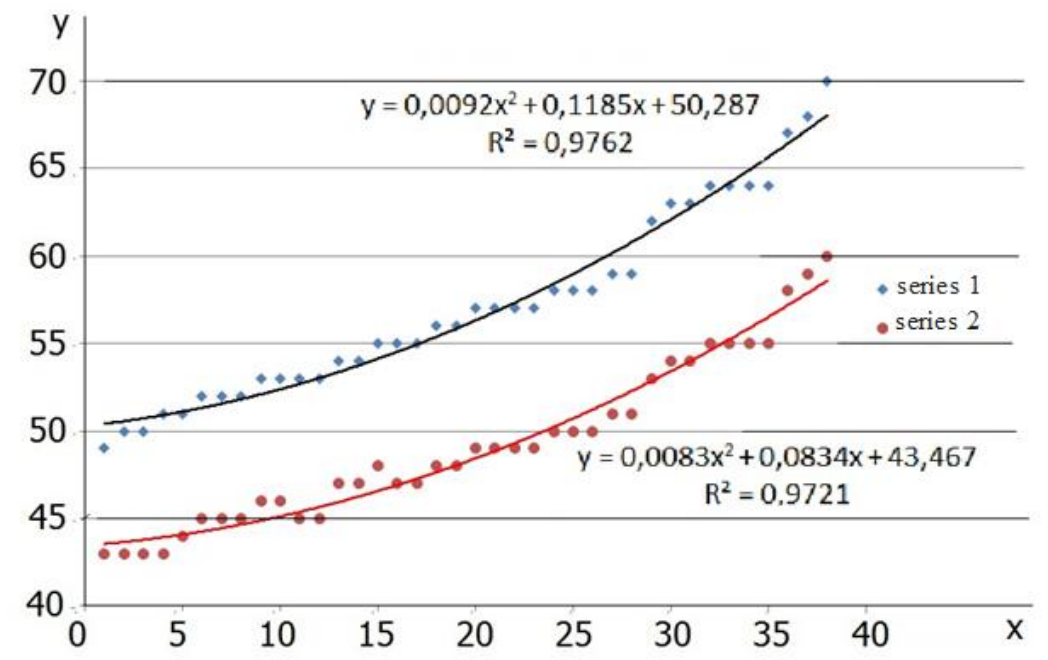

Fig. 1. Agrochemical (series 1) and environmental (series 2) assessment points of the land plots state.

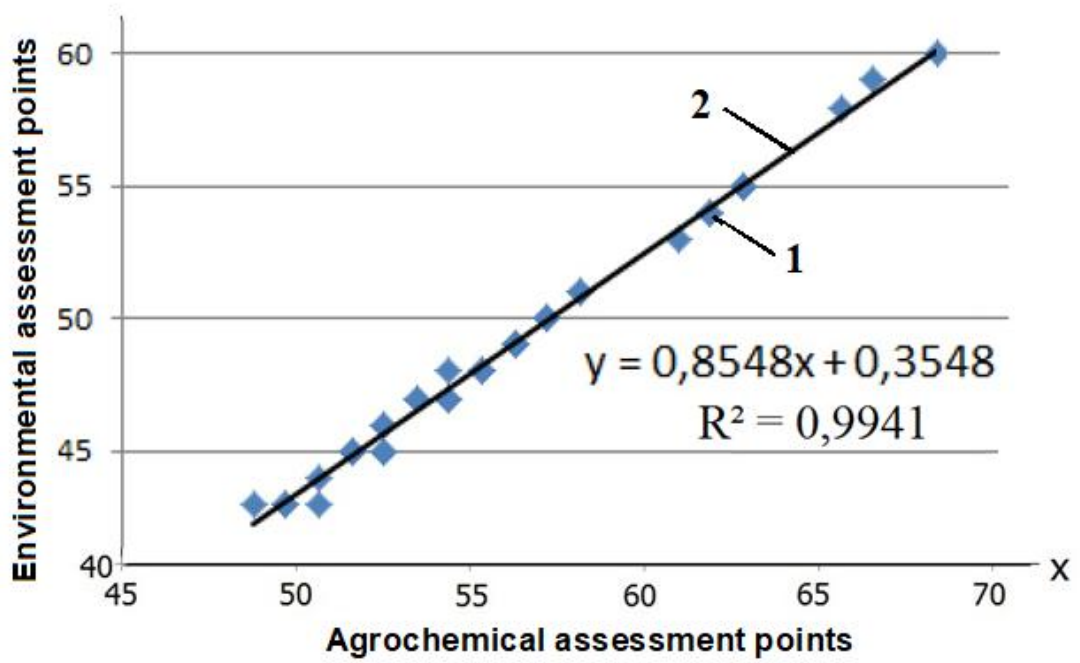

Fig. 2. Correlation between agrochemical (x) and ecological-agrochemical (y) assessment points, 1 -experimental points, 2 -trend line. 
Digitalization and digital transformation require constant mastering of latest digital technologies. In land management, informatization and digitalization are slow developing and this forms a potential threat that innovative enterprises, which provide fast service surveying will displace small businesses entities from the market. The digital revolution is noticeable very much in production: Ukraine is too dependent on foreign manufacturers of equipment; digital cadastral maps and plans supplanted paper ones; laser tape measures have replaced measuring tapes; there is a rapid aging of tools - surveying instruments and other equipment; news of geodesy, land management and cadastre are being derived from Instagram, Facebook, scientifically proved information is now sought not in the library, but on Wikipedia or YouTube. In the future, digitalization will lead to increase in labor productivity and creation of new demand occupations. It has both advantaged and drawbacks. The worst negative consequence, in our opinion, is the disappearance of a series of popular and traditional trades, leading to the growth of unemployment and social tension in society, and this will entail the decrease of the total income of society and reduction of personal space.

We believe that digitalization in geodesy and land management consists in the analysis (which will be of a recommendatory nature), modeling (forecast indicators of analysis results), forecasting (adaptation to real time and making optimal design decisions) and monitoring of digital processes (deeper development and work with digital services, geodetic information systems, databases and innovative components). It is clear that all this requires constant monitoring of their implementation and leads to increased productivity and competitiveness in the industry. In the figure 3 , it is presented the essence of digitization and digital transformation in geodesy and land management.

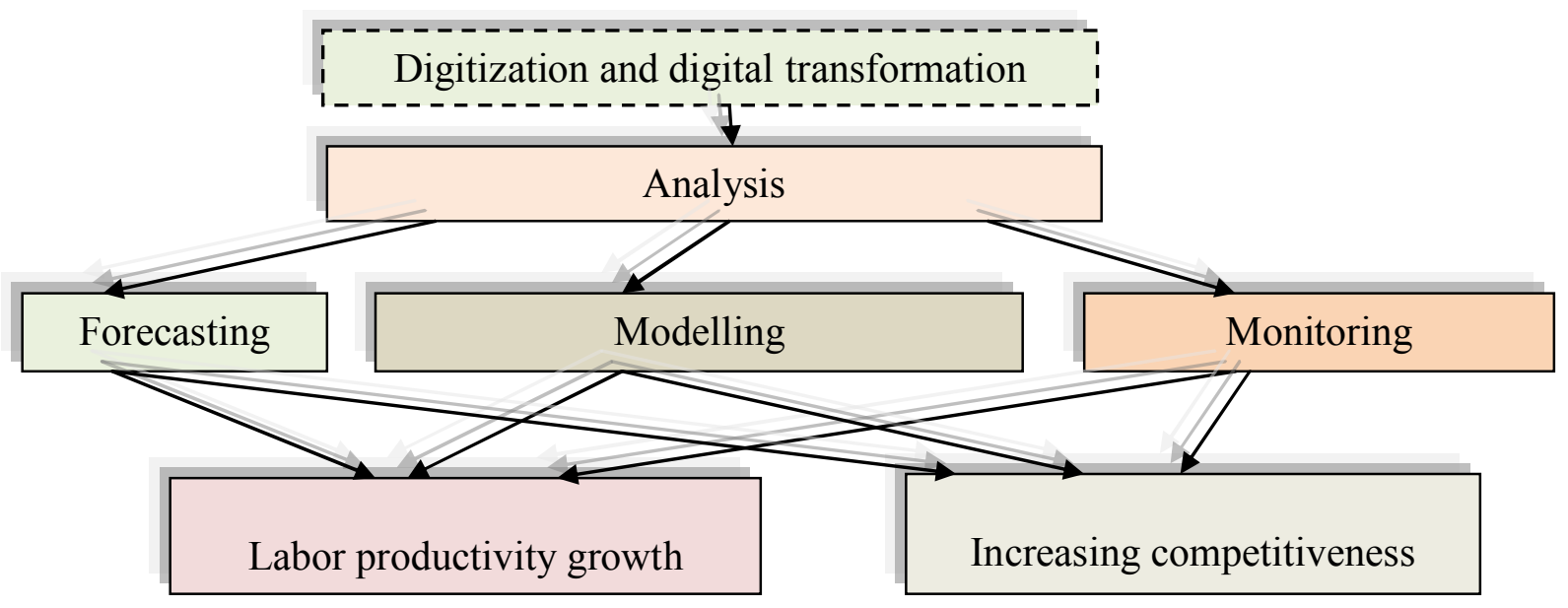

Fig. 3. The essence of digitization and digital transformation in geodesy and land management.

The current research on the issue confirms that platform business is an important area of enterprise development (including land management). We propose to create a digital platform that will stimulate innovation, increase choice, convenience, and market transparency, meet supply and demand, reduce costs in the field of geodesy, land management and cadastre. For example, it is useful to create a platform FieldSharing - interaction between landlords and tenants, Farmer - interaction between farmers and consumers (consumers should receive quickly and directly, without intermediaries, safe and high-quality farm products, farmers will obtain a stream of orders, that will allow them to increase the utilization of goods).
The use of information technology industry in the studied area is exercised in development and implementation of the regulatory and legislative framework, standardization of information; developing products (terrain surveys, land assessment, making design decisions, formation of land management projects, etc.), preparation and adjustment of this land management production; registration of planning and cartographic materials, electronic registrations and application processing, usage of information processing centers in the production process.

Unique technology that protects exchange information entities from the threat to disclose confidential information and provides reliability of 
obtained information is the block-chain technology, which allows storing property rights data and any other important information. In Ukraine, The State Land Cadastre has used block-chain technology since 2017. This provides reliable data synchronization, prevents data substitution as a result of external interference and let carry out public control over the system. This technology is implemented in the system of electronic trades of seized property SETAM OpenMarket. Block-chain technology also was used for the first online auction for the lease of public lands, for registration of property titles and for regular monitoring of land relations. This is the best tool to ensure absolute transparency and unconditional confidence in those data.

Thus, studying informatization, digitalization and digital transformation, it is expedient to emphasize the urgent problem in our country in a narrowly specialized field - creating advantages in obtaining modern land management education, production practice with the use of latest software, organization of new jobs, business development in the geodesy, land management and cadastre.

Digital technologies are actively introduced into modern geodesy and land management, which are rapidly becoming more high-tech, in geodesy it applies to both in-house and field work, which have recently been automated and digitized: leveling, deformation monitoring, topographic surveying, inhouse preparation of topographic plans, archive tablets for funds and so on. GNSS receivers with GPS positioning system accelerate the work of surveyors in the field in many times. The use of drones enormously simplifies the work and allows to build a threedimensional terrain model and use it in design. It is important that with the use of unmanned aerial vehicles surveying of large undeveloped areas is much faster and cheaper for the customer. However, digitization will not completely replace the manual work of the surveyor, such as setting up equipment and manual processing of data obtained using modern technologies to create a topographic survey that meets the requirements of regulatory documents.

Despite the active introduction of digital technologies in the industry, in the coming years we should not expect full automation of every process, because even a robotic tachymeter or the most modern laser scanner requires the participation of the operator.

In-house processes are being automated, it is developed software that transmits the obtained data of geodetic measurements directly from the worksite to cloud services, which automatically generate point clouds and digital terrain models, but more complex work is carried out in a semi-automatic mode or requires human participation. Western scientists are conducting research on the use of artificial intelligence to process large arrays of spatial data, especially clouds of laser reflection points, classification by type, but so far they are in their early stage. Domestic surveying suffers from a weak scientifictechnical provision of industry through the utilization of surveying equipment and software produced abroad.

Thus, while considering modern GIS technologies, we came to the conclusion of the necessity of realignment and improvement of cartographic and geodetic activities through information globalization, development of market conditions and competition with various sectors that affect the state and lane perspectives of development of geodesy, cartography and land management. The introduction of digital space technology leads to going beyond traditional methods and technologies of geodesy and cartography.

Conclusions. The digital transformation in Ukraine is quite slow, which puts Ukrainian business in a non-competitive position. While studying practical implementation of digitization in surveying and land management, the authors of the research noted the active digital revolution in land management production and outlined the nature and features of digitization and digital transformation in the investigated area. In order for geodesy and land management to remain in the list of modern popular professions, it is necessary to make a radical change of its structure and content and reorient the industry to expand the segment of knowledge in the field of digital technology, to turn surveyors to IT professionals. After all, lack of experience and required skills level can lead to innovative threats and risks. Further research should be devoted to the development of artificial intelligence and automation of processes in the field of geodesy and land management, although there is a risk of losing related professions.

The experience in teaching process digitalization shows that deep examination of the core methods of programming and material support is a necessary condition to obtain reliable results.

\section{References}

1. Bakhchevan E. V., Danko T. O. Digital transformation of the economy. Models of economic development: the latest technologies in management, accounting 
and finance: Coll. of scient. works on materials in USPC. 22.11. 2019. P. 32-34. URL: http://www.otei.odessa.ua/ (Last accessed: 12.03.2020).

2. Artemov V. O., Bakhchevan E. V., Danko T. O. Trends in e-commerce development in Ukraine. Scientific Bulletin of the Odessa National Econ. Un-ty. 2018. № 10 (262). P. 13-35. URL: http://n-visnik.oneu.edu.ua/ collections/ 2018/262/pdf/13-35.pdf(Last accessed: 10.03.2020).

3. Movchan T. V. Forecasting models of the management in the use and protection of land resources at the regional level: monograph. Odessa, 2010. $178 \mathrm{p}$.
4. Gudz O. E. Digital economy: change of values and landmarks in enterprise management. Economics. Management. Business. 2018. № 2(24). URL: http://www.dut.edu.ua/uploads/p_1010 10116202 (Last accessed: 12.03.2020).

5. Apalkova V. V. Conception of the development of the digital economy in the European Union and the prospects of Ukraine. Visnyk Dnipropetrovsk National University. Series: Innovation Management. 2015. Issue 4. P. 9-18.

Стаття надійшла 22.07.2020 